

\title{
EFEKTIVITAS MEDIA VIDEO DALAM PENINGKATAN PENGETAHUAN PETANI TERHADAP BUDIDAYA EDAMAME DI KELOMPOK TANI SEDERHANA, KELURAHAN BANDUNGAN, KABUPATEN SEMARANG
}

\section{Effectiveness of Video in Improving Knowledge of Farmers about Edamame Cultivation In The Sederhana Farmer Group, Bandungan, Semarang Regency}

\author{
Muhammad Asadullah, Sriroso Satmoko, Dyah Mardiningsih \\ Program Studi S1 Agribisnis Fakultas Peternakan dan Pertanian \\ Universitas Diponegoro \\ E-mail: muhammad.asadullah@yahoo.com
}

Diterima 07 Maret 2018, disetujui 06 Mei 2018

\begin{abstract}
ABSTRAK
Penelitian ini bertujuan untuk mengukur efektivitas media video sebagai media untuk meningkatkan pengetahuan petani tentang budidaya edamame. Penelitian dilakukan pada tanggal 1 November - 20 Desember 2017. Dua puluh petani anggota Kelompok Tani Sederhana dipilih sebagai responden. Penelitian ini merupakan penelitian eksperimental dengan model one group pretest-postest experimental research, yaitu dengan membandingkan mengetahuan petani tentang budidaya Edamame sebelum dan sesudah penayangan video dengan metode uji Paired Sample t-Test. Hasil penelitian menunjukkan bahwa penggunaan media video efektif secara signifikan meningkatkan tingkat pengetahuan petani tentang budidaya edamame dengan nilai signifikansi uji Paired Sample t-Test sebesar 0,000. Berdasarkan rata-rata hasil tes sebelum dan sesudah penayangan video didapat peningkatan nilai tes sebesar 54,95\%.
\end{abstract}

Kata kunci : edamame, efektivitas media, kelompok tani, video

\begin{abstract}
The objective of this research was to measure the effectiveness of video as a communication medium to improve knowledge of vegetables farmers about Edamame cultivation. The research was conducted on November 1st, 2017 - December 20th, 2017. Twenty farmers which members of Sederhana farmer group had chosen as the respondents. This research was an experimental research with one group pretest-post experimental research model, by comparing the level of knowledge of farmers about the cultivation of edamame before and after the video presentation with Paired Sample t-Test method. Based on the results of the research, it found that the use of video significantly increased the level of knowledge of farmers about edamame cultivation with the significance value of Paired Sample T-Test is 0.000 . The mean tests score increased by $54.95 \%$ before and after the video presentation.
\end{abstract}

Key Word : edamame, farmer group, media effectiveness, video 


\section{PENDAHULUAN}

Edamame adalah jenis tanaman kedelai yang terkenal di Jepang, edamame sering juga disebut sebagai kedelai jepang. Edamame yang umumnya dijual secara segar dan dikonsumsi sebagai kedelai rebus, disukai oleh masyarakat Jepang, Cina, dan Korea. Benihnya semula berasal dari Jepang. Jenis kedelai ini terkenal dengan ukuran biji yang besar. Indonesia adalah negara keempat di Asia yang berhasil mengembangkan dan mengekspor edamame ke Jepang setelah Taiwan, Cina, dan Thailand. Dikarenakan pasar yang spesifik, edamame memiliki harga yang stabil dan relative tinggi di pasaran. Diharapkan edamame dapat dijadikan salah satu komuditas pertanian unggulan di Indonesia dalam meningkatnya tingkat persaingan bisnis global. Untuk itu diperlukan pengenalan serta penyuluhan lebih lanjut kepada petani awam tentang potensi dan budidaya edamame sebagai alternatif komuditas hortikultura unggulan.

Berdasarkan UU No. 16 Tahun 2006 tentang sistem penyuluhan pertanian dijelaskan sistem penyuluhan pertanian, perikanan, dan kehutanan yang selanjutnya disebut sistem penyuluhan adalah seluruh rangkaian pengembangan kemampuan, pengetahuan, keterampilan, serta sikap pelaku utama dan pelaku usaha melalui penyuluhan. Kegiatan penyuluhan akan berjalan lebih efektif bila sasaran penyuluhan berada pada usia produktif (15-64 tahun). Pada usia ini petani dinilai cukup aktif dalam kegiatan bertani, dalam usia yang produktif akan lebih responsif dalam menerima inovasi dibandingkan dengan orang yang telah lanjut (Yunasaf dan Tasripin, 2012). Pesan atau informasi akan lebih mudah diserap secara tepat oleh seseorang bila penyampaian informasi dilakukan dalam kondisi dan metode yang menarik bagi sang penerima pesan (Pritandhari, 2015). Petani dengan latar belakang pendidikan rendah cenderung tertarik pada informasi-informasi baru yang bersifat praktis. Sedangkan petani yang memiliki latar belakang pendidikan tinggi
(SLTA dan di atasnya) cenderung tidak tertarik pada kegiatan penyuluhan, hal ini karena petani tersebut cenderung memiliki pengetahuan dan pengalaman yang lebih berkembang dari materi penyuhan itu sendiri, namun mereka lebih mampu menerima informasi-informasi yang teoritis dan mampu menerapkan ke dalam praktik di lapangan (Baba et al., 2011).

Secara umum media penyuluhan dapat diartikan sebagai alat bantu atau bahan penyuluhan yang akan disampaikan oleh para penyuluh kepada sasaran penyuluhan. Video serta poster/leaflet walau belum banyak diterima oleh petani, namun berpotensi sebagai media penyuluhan yang efektif, karena mendengar serta melihat (gambar) diakui sebagai salah satu metode komunikasi yang disukai (Paramita, 2013). Media video pembelajaran adalah media yang menyajikan audio dan visual yang berisi pesan-pesan pembelajaran baik yang berisi konsep, prinsip, prosedur, teori aplikasi untuk membantu pemahaman terhadap suatu materi pembelajaran (Pritandhari, 2015). Film dan video berguna untuk mengembangkan dan memperkuat motivasi karena dapat membangkitkan keterlibatan emosi petani pada masalah yang ingin didiskusikan penyuluh. Disamping itu video sangat cocok untuk menggambarkan proses kegiatan pertanian yang panjang menjadi ringkas dan lebih menarik (Hamalik, 2011). Evaluasi peningkatan pengetahuan petani dapat dilakukan dengan membuat standar-standar kompetensi terlebih dahulu, evaluasi yang didasarkan pada suatu standar kompetensi akan memberikan gambaran tingkat pengetahuan peserta didik yang berkaitan dengan kompetensi terkait (Sanjaya, 2008). Penelitian ini bertujuan untuk mengukur efektivitas media video sebagai media untuk meningkatkan pengetahuan petani tentang budidaya edamame. Manfaat dari hasil penelitian ini diharapkan bisa menjadi bahan kajian dalam pertimbangan media penyuluhan. 


\section{METODE PENELITIAN}

Penelitian dilaksanakan pada tanggal 1 November 2017 - 20 Desember 2017 dengan sasaran penelitian adalah Kelompok Tani Sederhana, Kelurahan Bandungan, Kecamatan Bandungan, Kabupaten Semarang. Pemilihan lokasi didasarkan pada lokasi alam yang sesuai untuk menanam komoditas edamame, serta berdasarkan hasil survey pendahuluan diketahui bahwa petani di lokasi tersebut belum mengenal komoditas edamame. Kondisi lokasi dan sasaran penelitian yang relevan dengan materi penelitian, diharap dapat memaksimalkan manfaat penelitian ini bagi petani.

Proses penelitian dilaksanakan dengan model one group pretest-postest experimental research. Penelitian dilaksanakan dengan mengukur tingkat pengetahuan tentang budidaya edamame pada 20 petani sayuran di Kelompok Tani Sederhana, sebelum dan sesudah pemaparan video.

Penyusunan materi video dan materi test didasarkan pada standar-standar kompetensi yang disusun terlebih dahulu. Video disusun dengan rujukan: (1) Publikasi artikel ilmiah dari Balai Penelitian Tanaman Kacang dan Umbi (Soewanto et al., 2016), (2) buku "Khasiat dan Budidaya Kedelai Edamame: Camilan Sehat dan Multimanfaat" (Pambudi, 2013), dan (3) hasil wawancara langsung dengan praktisi budidaya edamame.

Pengukuran dilakukan dengan instrumen pretest dan posttest. Pemilihan responden dilakukan dengan kriteria sebagai berikut: (1) laki-laki atau perempuan yang berstatus anggota aktif dalam Kelompuk Tani Sederhana dan berdomisili di Kelurahan Bandungan, Kecamatan Bandungan, (2) berada pada usia produktif (15-64 tahun),

(3) belum mengenal komoditas edamame, (4) dapat membaca dan menulis/tidak buta huruf, (5) dapat melihat dan mendengar dengan jelas serta memahami Bahasa Indonesia dengan baik.

Penyusunan materi video dan pertanyaan dalam test didasarkan pada standar-standar kompetensi yang telah disusun terlebih dahulu. Distribusi soal berdasarkan standar kompetensi sebagai berikut:

(1) Standar kompetensi Pengenalan Tanaman Edamame memiliki jumlah soal sebanyak 4 soal (soal nomor 1-4),

(2) Standar kompetensi Pengadaan Benih Edamame dan Perisiapan Penanaman memiliki bobot jumlah soal sebanyak 10 soal (soal nomor 5-14),

(3) Standar kompetensi Tanam dan Perawatan memiliki bobot jumlah soal sebanyak 9 soal (soal nomor 15-23),

(4) Standar kompetensi Panen dan Pascapanen memiliki bobot jumlah soal sebanyak 4 soal (soal nomor 2327),

(5) Standar kompetensi Pemasaran dan Kemitraan Usahatani memiliki bobot jumlah soal sebanyak 3 soal (soal nomor 28-30).

Dasar penilaian hasil tes adalah dengan pemberian nilai 1 untuk soal dengan jawaban benar dan nilai 0 untuk jawaban yang salah. Sebelum dilakukan proses eksperimen yang sebenarnya, instrumen penelitian diuji coba terlebih dahulu dengan uji validitas dan uji reliabilitas. Pengujian validitas dan reliabilitas dilakukan dengan mengujikan instrument penelitian kepada 15 petani saat studi pendahuluan dengan menggunakan metode pra-ekspreimen one shot case study, yaitu pemberian perlakuan dilakukan pada permulaan dan langsung dilakukan posttest (Yusuf, 2014).

Uji validitas dan reliabilitas diolah dengan perhitungan korelasi biserial. Dengan dasar pengambilan keputusan jika nilai $t$ hitung $>\mathrm{t}$ tabel, maka data dikatakan valid. Jika nilai $\mathrm{t}$ hitung $<\mathrm{t}$ tabel maka data dikatakan tidak valid. Rumus korelasi biserial antara lain sebagai berikut:

$r_{\text {pbis }}=\frac{\text { Mp-Mt }}{\text { SDt }} \sqrt{\frac{p}{q}}$

Keterangan :

rpbis : koefisien korelasi biserial

Mp : mean skor subjek yang menjawab betul pada butir soal yang dicari 


$$
\begin{array}{ll}
\text { Mt } & : \text { mean total skor } \\
\mathrm{Sdt} & : \text { standar deviasi total skor } \\
\mathrm{p} & : \text { proporsi responden yang menjawab } \\
& \text { benar } \\
\mathrm{q} & : \begin{array}{l}
\text { proporsi responden yang menjawab } \\
\text { salah }(1-\mathrm{p})
\end{array}
\end{array}
$$

Uji reliabilitas untuk menguji sejauh mana instrumen ukur dapat dipercaya untuk menjelas kondisi yang ada, pengujian dilakukan dengan uji Kuder-Richardson 20 (KR-20), karena uji KR-20 cocok untuk bentuk data yang didapat dari hasil tes yang merupakan data dikotomi, yaitu terdiri dari dua nilai saja (Yusuf, 2014). Dasar pengambilan keputusan antara lain bila nilai koefisien reliabilitas $>0,7$ maka dianggap reliabel. Berikut rumus perhitungan KR-20:

$\mathrm{KR}_{20}=\left(\frac{\mathrm{n}}{\mathrm{n}-1}\right) \frac{\mathrm{SD}^{2}-\Sigma \mathrm{pq}}{\mathrm{SD}^{2}}$

Keterangan :

$\begin{array}{ll}\mathrm{KR}_{20} & : \text { koefisien reliabilitas } \\ \mathrm{n} & : \text { kumlah item soal } \\ \mathrm{SD} & : \text { standar deviasi } \\ \mathrm{p} & : \text { proporsi responden yang menjawab } \\ & \text { benar } \\ \mathrm{q} & : \text { proporsi responden yang menjawab } \\ & \text { salah }(1-\mathrm{p})\end{array}$

Uji komparasi dilakukan dengan uji paired sample t-test menggunakan program SPSS. Pengambilan kesimpulan jika nilai probabilitas $<0,05$ maka terdapat perbedaan signifikan pada tingkat pengetahuan antara sebelum dan sesudah penayangan video. Jika nilai probabilitas $>0,05$ maka tidak terdapat perbedaan signifikan pada tingkat pengetahuan petani antara sebelum dan sesudah penayangan video. Atau berdasarkan nilai t hitung, jika t hitung berada pada daerah penerimaan $-\mathrm{t}_{\operatorname{tabel}(\alpha)}<\mathrm{t}<+\mathrm{t}_{\text {tabel }(\alpha)}$ maka tidak ada perbedaan signifikan pada tingkat pengetahuan petani antara sebelum dan sesudah penayangan video (Yusuf, 2014).

\section{HASIL DAN PEMBAHASAN}

\section{Karakteristik Responden}

Seluruh responden merupakan petani sayuran yang menggarap lahan miliknya sendiri dengan berbagai jenis komoditas sayuran, antara lain: cabai, tomat, kubis, dan lain-lain. Seluruh anggota aktif dalam Kelompok Tani Sederhana merupakan lakilaki yang merupakan kepala rumah tangga dalam keluarga petani. Oleh sebab itu seluruh responden yang dipilih berjenis kelamin lakilaki dengan rentan usia produktif mulai dari umur 30 tahun sampai umur 60 tahun. Pada usia ini petani sudah aktif dalam kegiatan bertani, dan relatif mudah menerima informasi. Hal ini sesuai dengan pendapat Yunasaf dan Tasripin (2012) bahwa pada usia produktif petani dinilai cukup aktif dalam kegiatan bertani, dalam rentan usia ini petani akan lebih responsif dalam menerima inovasi dibandingkan dengan orang yang telah lanjut.

Seluruh responden memiliki latar belakang pendidikan dibawah SLTA/ sederajat, sebagian besar merupakan tamatan $\mathrm{SD} /$ sederajat sebanyak 17 orang dan tamatan SMP/sederajat sebanyak 3 orang. Kondisi ini dinilai sangat mendukung kegiatan penyuluhan, karena tingkat pendidikan yang rendah memiliki keuntungan dimana peserta penyuluhan akan lebih tertarik dengan informasi-informasi yang diberikan selama penyuluhan. Peserta penyuluhan dengan latar belakang pendidikan rendah (setara SLTP dan di bawahnya) cenderung memiliki tingkat pengetahuan yang masih sedikit, sehingga penentuan materi penyuluhan akan lebih mudah untuk dapat menarik rasa ingin tahu peserta penyuluhan. Hal ini sesudai dengan pendapat Baba (2011) bahwa petani yang memiliki latar belakang pendidikan tinggi (SLTA dan di atasnya) cenderung tidak tertarik pada kegiatan penyuluhan, hal ini karena petani tersebut cenderung memiliki pengetahuan dan pengalaman yang lebih berkembang dari materi penyuhan itu sendiri. 


\section{Hasil Uji Validitas dan Reliabilitas}

Berdasarkan hasil perhitungan validitas dengan rumus (1) didapatkan hasil koefisien korelasi biserial masing-masing soal. Angka tersebut lalu dibandingkan dengan nilai $t$ tabel dengan df : $15-2=13$ dan nilai derajat ketelitian 0,05 yaitu sebesar 0,514. Diketahui seluruh nilai koefisien korelasi biserial lebih besar dari $\mathrm{t}$ tabel, sehingga seluruh soal dianggap valid.

Berdasarkan hasil perhitungan reliabilitas menggunakan rumus (2) didapat nilai koefisien sebesar 0,973, karena nilai tersebut lebih besar dari standar yang ditentukan $(>0,700)$ maka instrumen tes yang digunakan dianggap reliabel. Berdasarkan hasil tersebut dapat dikatakan instrumen yang digunakan dalam penelitian sudah cukup valid dan reliabel.

\section{Efektivitas Video Sebagai Media Penyuluhan}

Berdasarkan hasil uji komparasi paired sample t-test menggunakan program SPSS versi 23 didapat hasil nilai signifikansi 0,000, dan nilai $\mathrm{t}$ hitung -11,356. Karena nilai signifikansi tersebut di bawah nilai derajat kepercayaan $5 \%$ dan $1 \%$, dan nilai t di luar daerah penerimaan $-\mathrm{t}_{\text {tabel }(\alpha)}<\mathrm{t}<+\mathrm{t}_{\text {tabel }(\alpha)}$ $\left(\mathrm{t}_{\text {tabel }(0,05), \mathrm{db}: 18}=1,789\right.$ dan $\mathrm{t}_{\text {tabel }(0,01), \mathrm{db}: 18}$ $=2,500$ ), maka dapat disimpulkan terdapat perbedaaan sangat signifikan pada tingkat pengetahuan petani akan tatacara budidaya edamame sebelum dan sesudah penayangan video sampai pada derajat kepercayaan $1 \%$.

Hasil nilai pretest dan postest beserta nilai rata-rata keduanya dapat dilihat pada Tabel 1. Berdasarkan hasil perhitungan diketahui rata-rata nilai pretest sebesar 14,65 sedangkan rata-rata nilai posttest sebesar 22,70 . Peningkatan yang terjadi pada nilai rata-rata sebelum dan sesudah penayangan video dapat dilihat pada Ilustrasi 1 .

Ilustrasi 1 menunjukan bahwa setelah satu kali penayangan video pada 20 orang sampel petani, terjadi peningkatan tingkat pengetahuan sebesar 54,95\% dari nilai awal sebelum penayangan. Peningkatan rata-rata
Tabel 1. Hasil nilai pretest dan postest

\begin{tabular}{ccc}
\hline No. Resp. & Nilai pretest & Nilai postest \\
\hline 1 & 18 & 25 \\
2 & 16 & 20 \\
3 & 8 & 13 \\
4 & 9 & 22 \\
5 & 8 & 12 \\
6 & 11 & 22 \\
7 & 17 & 23 \\
8 & 14 & 19 \\
9 & 15 & 27 \\
10 & 14 & 25 \\
11 & 13 & 16 \\
12 & 14 & 23 \\
13 & 17 & 27 \\
14 & 12 & 22 \\
15 & 18 & 25 \\
16 & 15 & 27 \\
17 & 17 & 25 \\
18 & 20 & 27 \\
19 & 21 & 26 \\
20 & 16 & 28 \\
\hline Jumlah & 293 & 454 \\
\hline Rata-rata & 14,65 & 22,7 \\
\hline & &
\end{tabular}

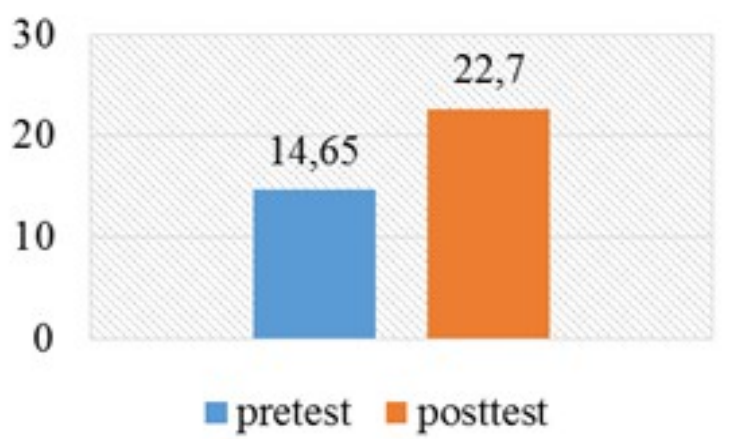

Ilustrasi 1. Grafik rata-rata nilai pretest dan posttest

nilai menunjukan bahwa media video yang telah dibuat telah berhasil menyampaikan informasi dan menyatukan persepsi petani secara tepat sesuai dengan tujuan kondisi yang diinginkan oleh sang pembuat video, ini sesuai Ban dan Hawkins (2008) bahwa media penyuluhan idealnya harus menarik dan jelas serta mampu menggiring setiap persepsi dari 


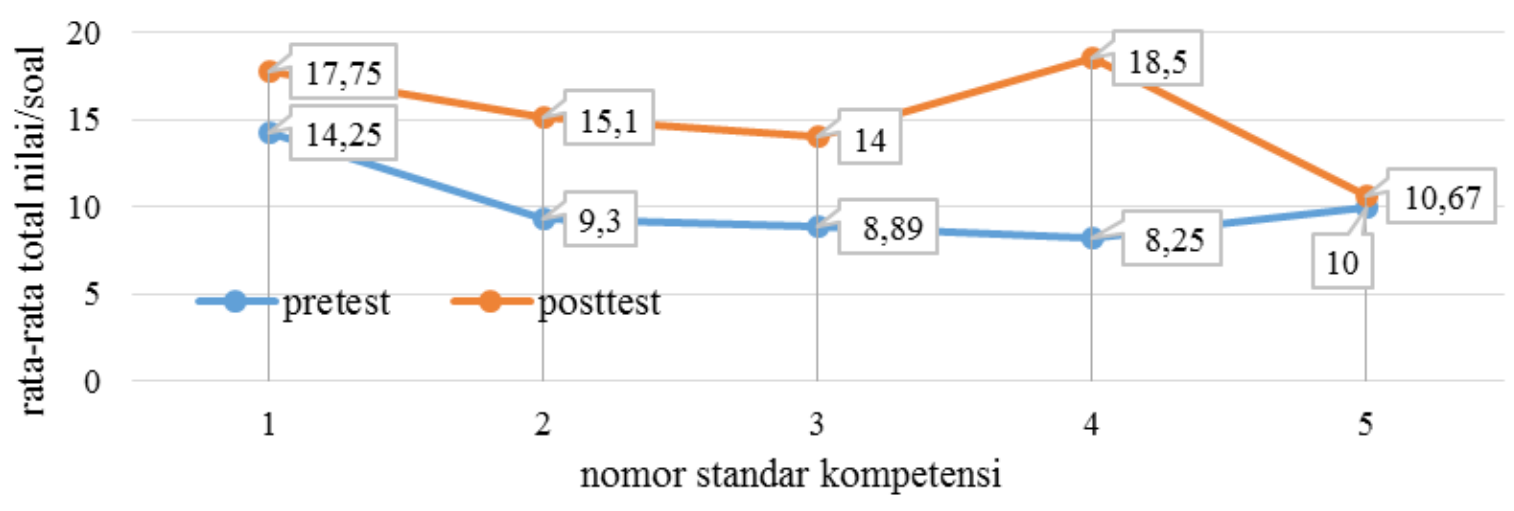

Ilustrasi 2. Grafik rata-rata total nilai tiap soal berdasarkan standar kompetensi

petani/target penyuluhan agar dapat menerima dan memproses informasi sesuai dengan yang diinginkan oleh penyuluh dengan penyimpangan seminim mungkin.

Untuk mendeskripsikan lebih lanjut kondisi pengetahuan petani sebelum dan sesudah penayangan, maka digunakan ratarata total nilai tiap soal pada masing-masing standar kompetensi. Pengelompokan atau distribusi soal berdasarkan standar kompetensi telah dijelaskan pada subbab Metode Penelitian. Hal ini sesuai dengan pendapat Sanjaya (2008) bahwa evaluasi yang didasarkan pada suatu standar kompetensi akan memberikan gambaran tingkat pengetahuan peserta didik yang berkaitan dengan kompetensi terkait.

Berdasarkan Ilustrasi 2 dapat diketahui bahwa pada kondisi sebelum penayangan video, petani responden memiliki tingkat pengetahuan terendah pada kompetensi nomor (4), yaitu tentang panen dan penanganan pasca panen dengan rata-rata nilai total per- soalnya 8,25 . Sedangkan petani memiliki tingkat pengetahuan tentang pengenalan dasar edamame relatif tinggi pada kompetensi nomor (1) dengan rata-rata nilai total per soalnya 14,25 .

Setelah penayangan video, seluruh nilai kompetensi meningkat, dengan peningkatan tertinggi pada kompetensi nomor (4) dengan peningkatan sebesar 10,25 poin, dan peningkatan terendah pada kompetensi nomor (5) sebesar 0,67 poin. Setelah penayangan video, nilai kompetensi petani secara berurutan dari yang tertinggi ke terendah sebagai berikut: kompetensi (4) 18,50 poin, kompetensi (1) 17,75 poin, kompetensi (2) 15,40 poin, kompetensi (3) 14,00 poin, dan kompetensi (5) 10,67 poin.

Selama penayangan video, antusiasme petani terlihat meningkat pada penayangan materi yang mengandung kompetensi bersifat teknis dan praktis, yaitu kompetensi penanaman hingga panen. Antusiasme petani dan ketertarikan petani menurun pada materimateri teoritis, seperti pada pengenalan materi kemitraan usahatani. Hal ini juga dapat terlihat dari tingkat peningkatan rata-rata total nilai tiap soal pada masing-masing kompetensi. Standar kompetensi (4) yaitu Panen dan Penanganan Pascapanen memiliki pengingkatan tertinggi, sedangkan Standar Kompetensi (5) memiliki tingkat peningkatan terendah. Pada penayangan mater-materi mengenai Standar Kompetensi (4) terdapat banyak narasi, ilustrasi dan dokumentasi bergerak, sehingga lebih menarik dan mudah diterima. Sedangkan penayangan materimateri mengenai Standar Kompetensi (5) sebagian besar hanya berisi tulisan dan narasi saja, sehingga dinilai kurang menarik bagi petani. Hal ini sesuai dengan pendapat Baba (2011) bahwa petani dengan latar belakang pendidikan rendah cenderung tertarik pada informasi-informasi baru yang bersifat praktis.

Perbedaan antusiasme tersebut berkemungkinan besar mempengaruhi daya serap petani akan materi yang bersangkutan. 
Hal ini sesuai dengan Pritandhari (2015) bahwa pesan atau informasi akan lebih mudah diserap secara tepat oleh seseorang bila penyampaian informasi dilakukan dalam kondisi dan metode yang menarik bagi sang penerima pesan.

\section{KESIMPULAN}

Berdasarkan hasil penelitian didapat bahwa penggunaan media video efektif secara signifikan meningkatkan tingkat pengetahuan petani mengenai budidaya edamame dengan nilai signifikansi uji Paired Sample t-Test sebesar 0,000 dengan nilai t hitung -11,356. Berdasarkan hasil tes sebelum dan sesudah penayangan video didapat peningkatan nilai tes sebesar 54,95\%. Disimpulkan bahwa penggunaan media video efektif secara signifikan meningkatkan pengetahuan petani mengenai budidaya edamame. Bagi peneliti yang hendak meneliti bidang sejenis, disarankan menelaah lebih lanjut pada perubahan-perubahan afektif dan psikomotorik petani, tidak terbatas pada perubahan kognitif saja.

\section{DAFTAR PUSTAKA}

Baba, S., Isbandi, T. Mardikanto, dan Waridin. 2011. Faktor-faktor yang mempengaruhi tingkat partisipasi peternak sapi perah dalam penyuluhan di Kabupaten Enrekang. JITP. 1(3): 193-208.

Ban, A. W. V. D. dan H. S. Hawkins. 2008. Penyuluhan Pertanian (cetakan ke-9). Kanisisus, Yogyakarta.

Hamalik, O. 2011. Proses Belajar Mengajar. Jakarta. Bumi Aksara.

Pambudi, S. 2013. Khasiat dan Budidaya Kedelai Edamame: Camilan Sehat dan Multimanfaat. Bantul. Pustaka Baru
Paramita, E., E. Martini, dan J. M. Roshetko. 2013. Media dan metode komunikasi dalam penyuluhan agroforestri : studi kasus di Sulawesi Selatan (Kabupaten Bantaeng dan Bulukumba) dan Sulawesi Tenggara (Kabupaten Konawe dan Kolaka). Prosiding. Seminar Nasional Agroforestri. Agroforestry Centre (ICRAF), Malang. p. 488-493.

Pritandhari, M. dan T. Ratnawuri. 2015. Evaluasi penggunaan video tutorial sebagai media pembelajaran semester IV program studi pendidikan ekonomi Universitas Muhammadiyah Metro. Promosi. 3(2): 11-20.

Republik Indonesia. 2006. Undang-undang No.16 Tahun 2006 tentang Sistem Penyuluhan Pertanian, Perikanan, dan Kehutanan. Lembaran Negara Republik Indonesia Tahun 2006 Nomor 92. Jakarta. Sekretariat Negara.

Sanjaya, W. 2008. Kurikulum dan Pembelajaran. Jakarta. Kencana Prenada Media Group.

Soewanto, H., A. Prasongko, dan Sumarni. 2016. Agribisnis Edamame untuk Ekspor. Malang. Balai Penelitian Tanaman Kacang dan Umbi.

Yunasaf, U. dan D. S. Tasripin. 2012. Peran penyuluh dalam proses pembelajaran peternak sapi perah di KSU Tandangsari Sumedang. Jurnal Ilmu Ternak. 12(1):41-46.

Yusuf, A. M.. 2014. Metode Penelitian: Kuantitatif, Kualitatif, dan Penelitian Ganbungan. Jakarta. Kencana. 